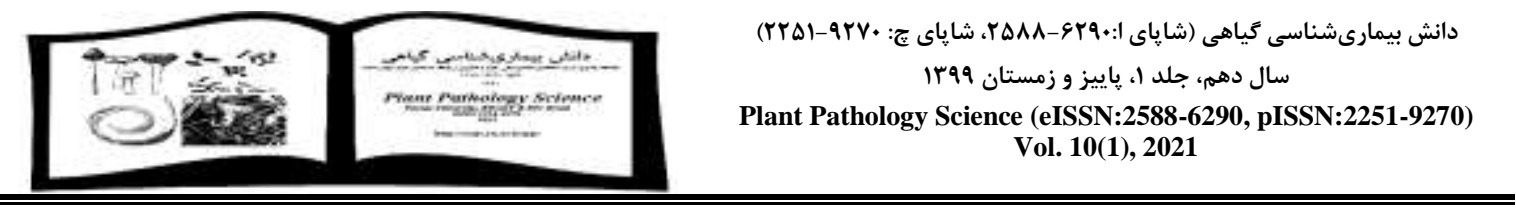

\title{
Research Article \\ The relationship between potato resistance to bacterial soft rot and expression of three PR genes
}

\author{
HOSSEIN PASALARI ${ }^{\bowtie}$ \\ Department of Agriculture, Minab Higher Education Center, \\ University of Hormozgan, Bandar Abbas, Iran
}

Received: 13.12.2020

Accepted: 20.07.2021

Pasalari H (2021) The relationship between potato resistance to bacterial soft rot and expression of three PR genes. Plant Pathology Science 10(1):76-85. Doi: 10.2982/PPS.10.1.76.

\section{Abstract}

Introduction: Changes in the resistance to bacterial soft rot in potatoes can be linked to the expression of pathogenesis-related (PR) genes. The aim of this study was to investigate the relationship between the accumulation of PR genes and the induction of resistance through infection of potato tuber cells with pathogenic bacteria at different temperatures in order to effectively combat bacterial soft rot disease in potatoes. Materials and Methods: Pectobacterium carotovorum 2A, Pectobacterium atrosepticum 36A, and Dickeya dadantii ENA49 were used in this study. For bacterial infection, the potato cultivars semi-resistant cultivar Scarab and susceptible cultivar Vesnianka, were used. The factorial experiment with three replications was carried out according to a completely randomized design. The relative level of mRNA copies of PR genes was determined by RT-PCR using primers of these genes. The mean values were compared according to the LSD test. Results: The experiments demonstrated the induction of PR-3, PR-5t and PR-10 in potato tuber cells in response to infection with $P$. carotovorum $2 \mathrm{~A}, P$. atrosepticum $36 \mathrm{~A}$ and $D$. dadantii ENA49. It has been shown that the degree of induction of resistance genes depends on the temperature and the potato cultivar. Conclusion: It can be concluded that significant changes in potato resistance to bacterial soft rot at temperatures of 28 and $33^{\circ} \mathrm{C}$ are associated with the expression of these PR genes.

Key words: Dickeya, Pectobacterium, Scarab, Vesnianka

$\bowtie$ hossein.pasalari@Hormozgan.ac.ir 


$$
\text { مقاله يثزوهشى }
$$

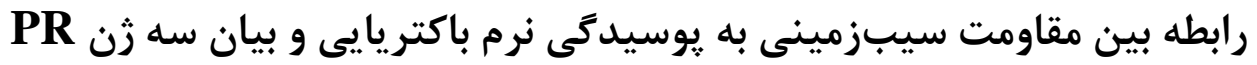

$$
\text { حسين קاسالارى }
$$

گروه كشاورىى، مجتمع آموزش عالى ميناب، دانشگاه هرمز گان، بندرعباس، ايران

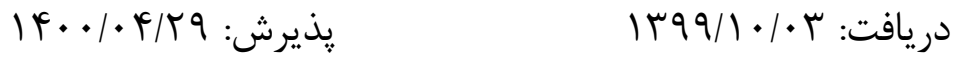

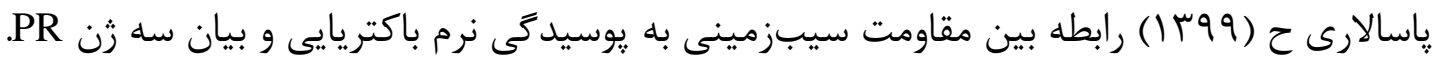

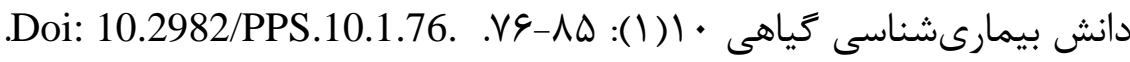

\section{جكيده}

مقدمه: تغيير در مقاومت سيبزمينى به يوسيدگى نرم باكتريايى ممكن است با بيان زنهاى مرتبط با بيمارىزايى(PR) ارتباط داشته باشد. هدف از اجراى اين يزوهش بررسى رابطه بين سطح بيان سه

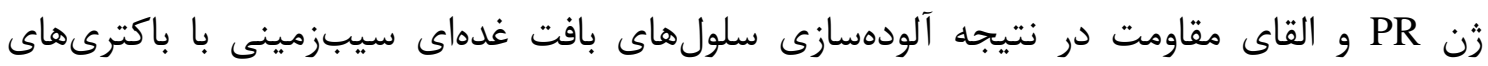
بيماركر در دماهاى مختلف به منظور مهار مؤثر بيمارى يوسيدكى نرم باكتريايى سيبزمينى بود. مواد و و روشها: باكترىهاى Pectobacterium ، Pectobacterium carotovorum 2A atrosepticum36A

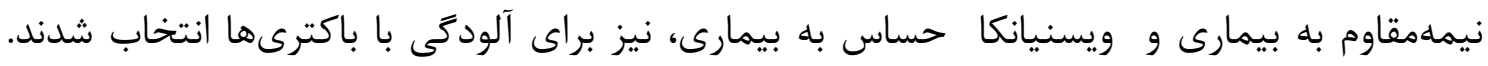

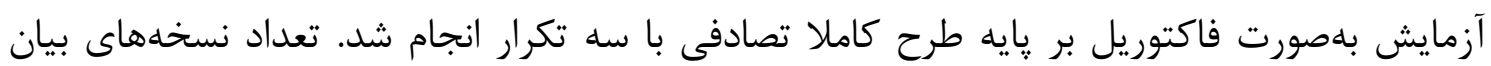
شده mRNA از زنهاى PR از طريق PCR در زمان واقعى با كمك آغازگرهاى مربوط به اين زبنها

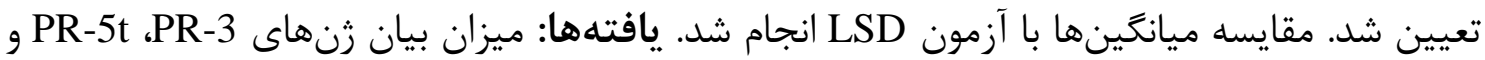
P. در سلولهاى غدههاى سيبزمينى در پاسخ به آلودكى به 9 atrosepticum D. dadantii ENA49، به دما و رقم سيب زمينى بستكى داشت. نتيجه گيرى: تغييرات معنى دار در

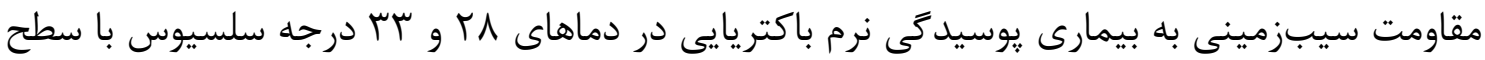
بيان اين سه زن PR وجود دارد.

وازگًان كليدى: Dickeya, Pectobacterium, Scarab, Vesnianka

\section{Introduction}

سيبزمينى نقش مهمى در تغذيه مردم جهان دارد و از نظر مقدار توليـد، جهـارمين محصـول جهـان

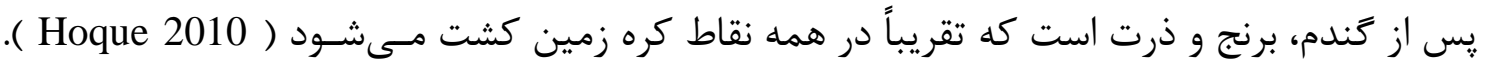
اين محصول استراتزيك در طول دوران رشد و يس از برداشت با مشكلات عديدهاى مواجه مىشود كه

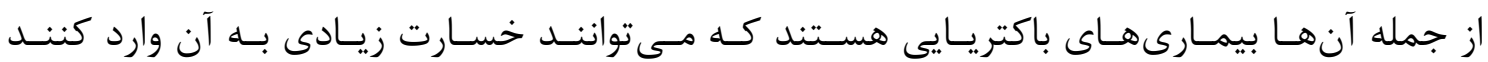


(Pectobacterium carotovorum (Moslemkhani and Mozafari 2016) Dickeya dadantii و Pectobacterium atrosepticum بافت سيبزمينى در گونههاى مختلف، در طول فصل رشد و در طول انبار شوند. يكى از ويزخىىهـاى بـاكترىهـاى مـذكور، توانـايى ترشـح تعـدادى آنـزيم تجزيسه كنـــده خــارج سـلولى (يكتوليتيـك و تروتئوليتيك) است كه به عنوان فاكتورهاى بيمارىزايى اين باكترىها عمل مي كننـد (Tratsiakova)

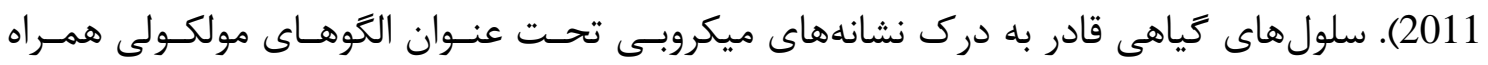

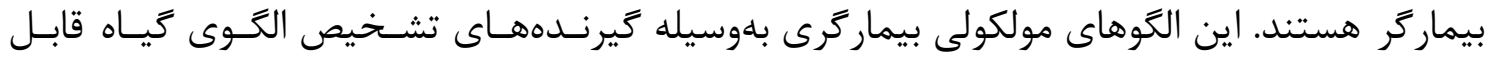

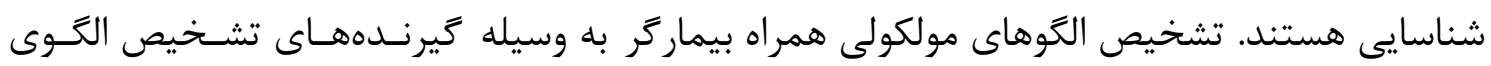

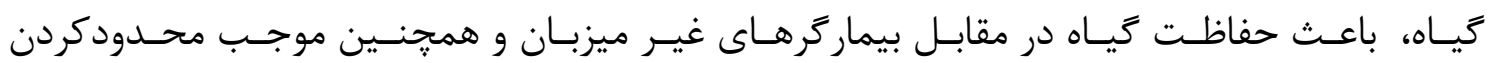

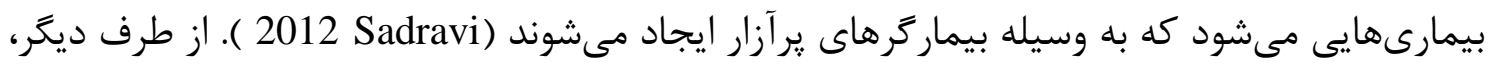

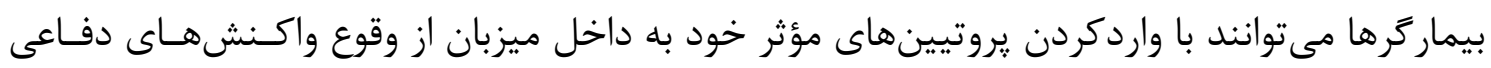

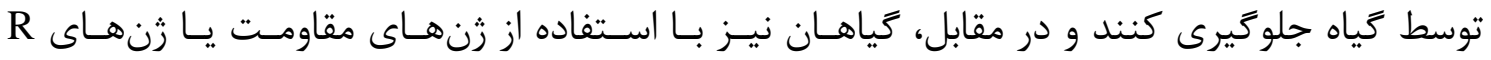
به صورت مستقيم يا غيرمستقيم باعث ممانعـت از عمـل يـروتيينهــاى مـؤثر بيماريزايى بيماركرها مىشوند ( Gholamnezhad 2017 ). همجنين اين پاسخهاى دفاعى مىتوانند به وسيله واكنش فوق حساسيت يا Hypersensitive Reaction) HR) و سيسـتم مقاومست اكتسـابى يـا نيز تشديد شوند (Systemic Acquired Resistance) SAR واقعى زنتيكى مولكولى نوين، مطالعه سازوكارهاى تنظيهم كننده فعاليت زن ها بـهـويـره زنهـاى رِاسـخ

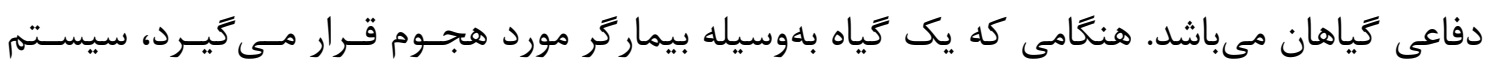
״ييجيدهاى از ياسخ دفاعى گياه فعال مىشود. در اين حالت، برنامهريزى مجدد بيان زنهاى مختلف در سلولها آغاز مىشود كه منجر به فعال شدن بيان آبشار زنهاى واكنش محـافظتى و خـاموش شـدن

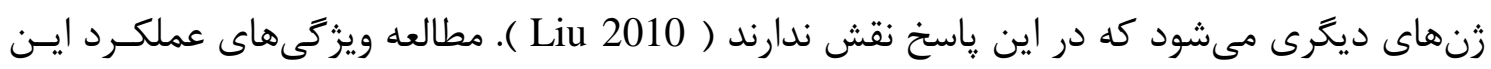

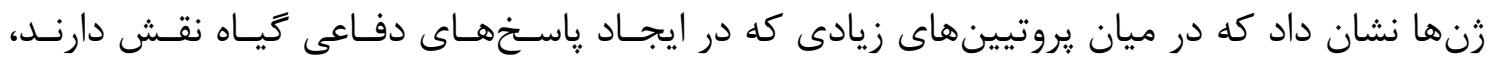

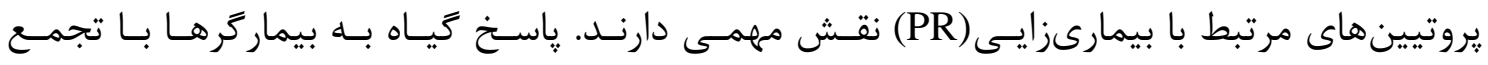
يروتيينهاى PR مرتبط است ( Van Loon et al. 2011). زن هاى مرتبط با بيمارىزايسى، يـك حـروه خاص از يروتيينهاى محافظ هستند كه در ياسخ به تأثيرات تنشزا و عفونت بيماركرها بيان مىشوند. يروتيينهاى PR در بسيارى از گونههاى گياهى يافت مىشوند و در حال حاضر بروتيينهاى توصـيف

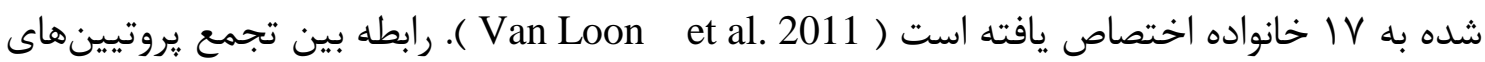
و مقاومت اكتسابى سيستميك در كياهان، منجر به اين فرض شده است كه بيـان ايسن زنهــا بـهـ عنوان نشانكرهاى اين مقاومت محسوب مىشود و نشان داده شده است كه انباشت اين يروتيينهـا بـا توسعه مقاومت به دست آمده در گياه ارتبـاط دارد ( Van Loon et al. 2011) ). نشـان داده شـده كــه 
سطح بيان زنهاى PR-1، PR-3 و PR-5 در كياهان سيبزمينسى بـهـ مقاومست آنهـا در برابـر قـارج Phytophthora infestans

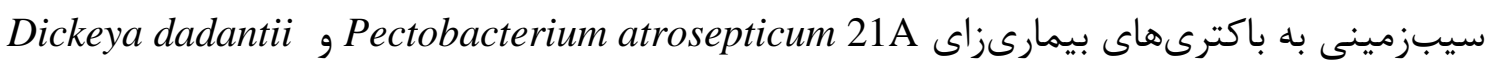

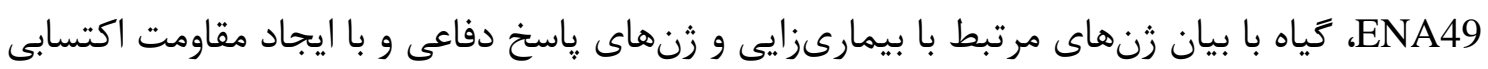

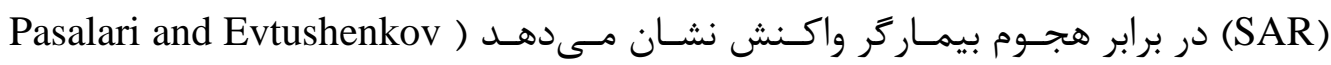

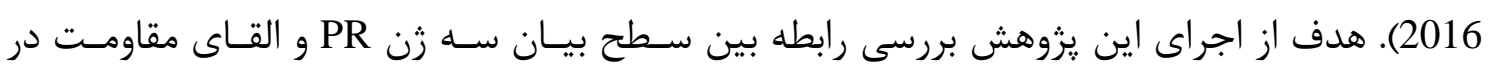

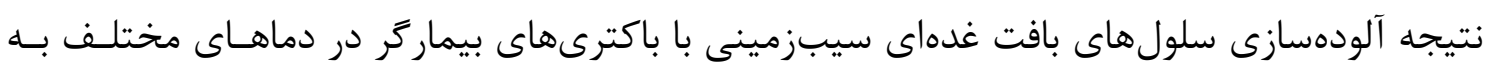

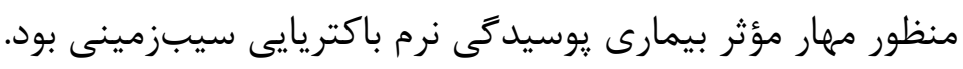

\section{Materials and Methods}

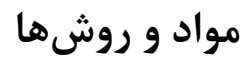

انتخاب رقمهاى سيب زمينى و سويههاى باكترىهاى عامل يوسيدكى نرم باكترىهاى P. A. atrosepticum 36A ، carotovorum 2A باكترىهاى بخش زيست مولكولى دانشكاه دولتى روسيه سفيد (بلاروس) انتخاب شدند. رقمهاى سيب زمينى اسكارب (Scarb) نيمه مقاوم و ويسنيانكا (Vesnianka) حساس به اين باكترىها از Pasalari 2020, موسسه تحقيقاتى سيبزمينى و سبزيجات آكادمى ملى بلاروس نيز انتخاب شدند 2010

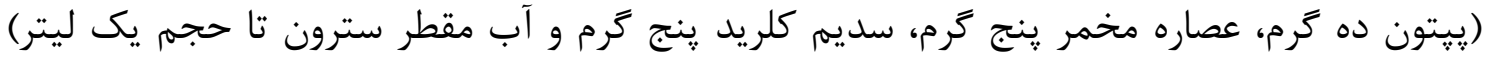

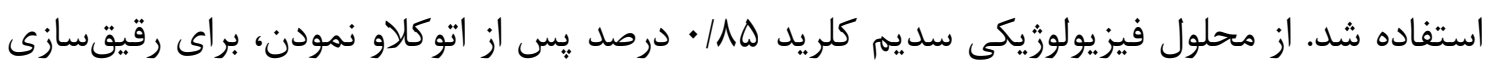

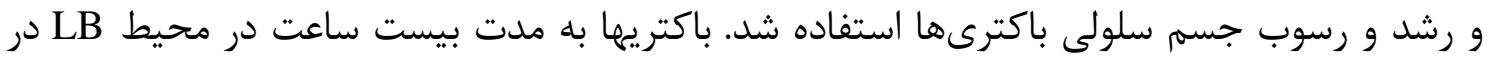
دماى \ د درجه سلسيوس رشد داده شدند. غدههاى سيبزمينى كه يس از برداشت بهوسيله الكل ضدعفونى شده بودند به كمك اسكاليل سترون، تكههايى به اندازه يك در يك سانتىمتر و ضخامت

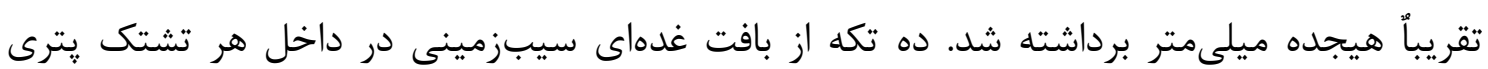

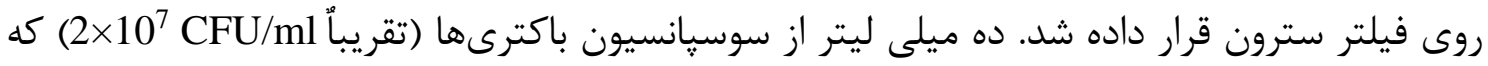
توسط محلول فيزيولوزيكى كلريدسديم سترون، رقيق شده بود، بر روى سطح آسيب ديده ديسكها كه بوسيله اسكاليل سترون ايجاد زخم شده بود، قرار داده شد ( Tratsiakova ) و سير سيس

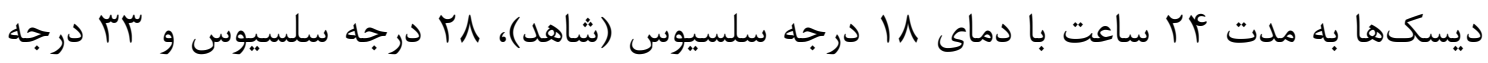
سلسيوس در تشتك يترى سترون نگهدارى شدند. آزمايش به صورت فاكتوريل بر پايه طرح كامل

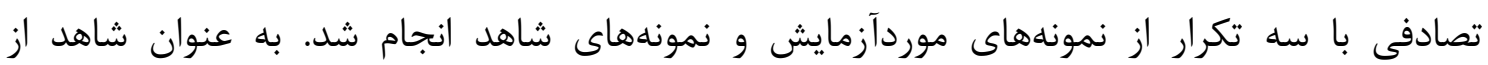
ديسكهاى غدهاى سيبزمينى رقمها موردنظر كه بوسيله باكترىهاى فوق آلوده نشده بودند و تحت 


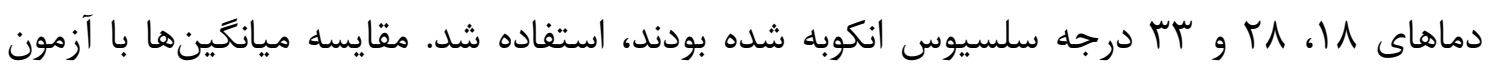
LSD در سطح احتمال ه درصد انجام شد.

استخراج RNA از بافت غدههاى سيبزمينى و سنتز إن إن صد ميلى گرم از بافت غدههاى سيبزمينى (در هر تيمار با سه تكرار) با نيتروزن مايع به صورت يودر درآمده و به لولههاى إيندورف منتقل شدند. سيس، استخراج RNA كل از اين موادكياهى با استفاده از كيت تجارى (Macherey-Nagel، آلمان) NucleoSpin RNA Plant و طبق دستورالعمل شركت سازنده آن انجام شد. از RNA كل جدا شده براى سنتز cDNA با استفاده از كيت تجارى سنتز Fermentas) RevertAidTM First Strand) cDNA شد. آزمون واكنش زنجيرهاى يليمراز در زمان واقعى (RT-PCR) با جفت آغازگرهاى اختصاصى براى هر رن و يك جفت كنترل داخلى (EF-1a) در دستخاه DNA-Technology) DT-96، روسيه) انجام شد (جدول (1). هر واكنش •r ميكروليترى، شامل ا ميكروليتر مسترميكس سايبرگرين (20X)

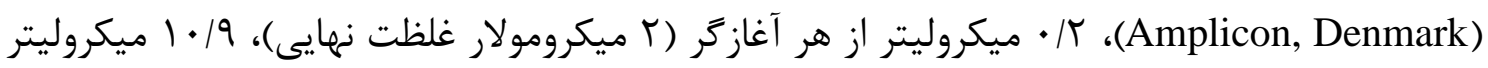
آب تيمار شده با ديس (DEPC water) و ا ميكروليتر سىدىاناى الكو (•ه نانوگرم بر ميكروليتر)

جدول l. مشخصات آغازگرهاى استفاده شده در اين يزوهش Table 1. Characteristics of the primers used in this research

\begin{tabular}{|c|c|c|c|c|}
\hline $\begin{array}{c}\text { آغازَّر } \\
\text { Primers }\end{array}$ & $\begin{array}{c}\text { توالى آغازكرها: } \\
\text { Primer sequences }\end{array}$ & $\begin{array}{c}\text { دماى } \\
\text { Annealing }\end{array}$ & $\begin{array}{c}\text { اندازه قطعه } \\
\text { Amplicon } \\
\text { size } \\
\text { Amsend }\end{array}$ & $\begin{array}{c}\text { منبع آغازَّر } \\
\text { Primer } \\
\text { source }\end{array}$ \\
\hline $\begin{array}{l}\text { PR-3- } \\
\text { Potato }\end{array}$ & $\begin{array}{l}\text { StPR3f } \\
\text { ATAAGCCATCATGCCACAACG } \\
\text { StPR3r } \\
\text { GCAGTATTCGGACCCATCCC }\end{array}$ & $56^{\circ \mathrm{C}}$ & $<110 \mathrm{bp}$ & $\begin{array}{c}\text { Tratsiakova } \\
2011\end{array}$ \\
\hline $\begin{array}{l}\text { PR-5-Potato } \\
\text { (Thaumatin) }\end{array}$ & $\begin{array}{l}\text { StPR5tf } \\
\text { ATCTCCCGTCTCGCATTTGC } \\
\text { StPR5tr } \\
\text { GGGCCAAACTTGGAACCTTAATG } \\
\text { LePR10f2 }\end{array}$ & $60^{\circ \mathrm{C}}$ & $<110 \mathrm{bp}$ & $\begin{array}{c}\text { Tratsiakova } \\
2011\end{array}$ \\
\hline PR-10 & $\begin{array}{l}\text { TATGAGTCAACAACAATTTCCC } \\
\text { LePR10r } \\
\text { TGGACCACCTTCAACAAAGTTC }\end{array}$ & $60^{\circ \mathrm{C}}$ & $<110 \mathrm{bp}$ & $\begin{array}{c}\text { Tratsiakova } \\
2011\end{array}$ \\
\hline EF-1 $\alpha$ & $\begin{array}{l}\text { StEF1 } \alpha \mathrm{f} \\
\text { TTGATGCTCTTGACCAGATTAACG } \\
\text { StEF1 } \alpha 2 \mathrm{r} \\
\text { ACGGGCACAGTTCCAATACC }\end{array}$ & $56^{\circ \mathrm{C}}$ & $\sim 1100 \mathrm{bp}$ & $\begin{array}{c}\text { Tratsiakova } \\
2011\end{array}$ \\
\hline
\end{tabular}




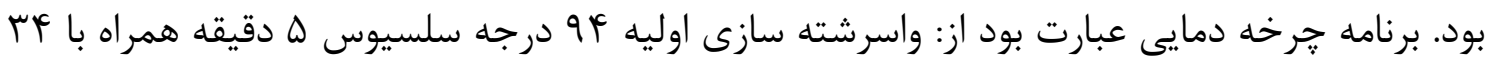

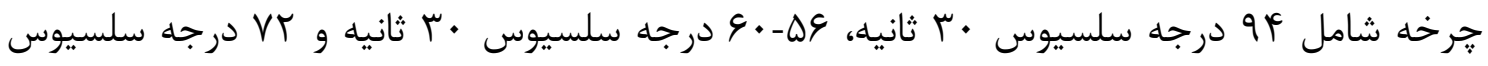

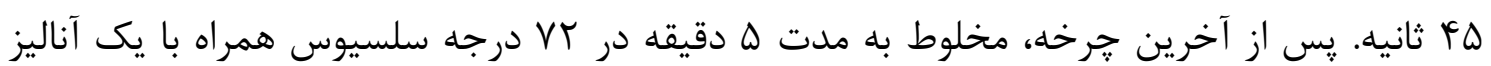
منحنى ذوب آغازگرها كه از • له تا عq درجه سلسيوس بود، نتحهدارى شد. جفت آغازگرهاى استفاده شده در اين يزوهش (جدول () مربوط به زنهاى مرتبط با بيمارىزايى سيبزمينى بودندكه از شركت ايرون Eurofins MWG Operon-Company (Ebersberg, Germany) سفارش داده شد. مقدار

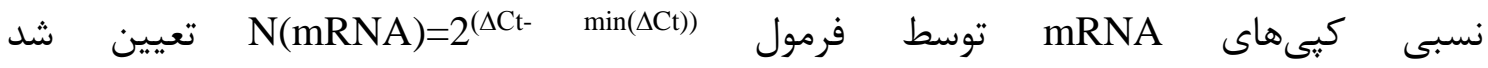

.( Livak and Schmittgen 2001)

\section{Results}

يافتهها

آناليز PCR نمونههاى cDNA جداشده و سنتزشده از بافت غدهاى سيبزمينى از جهت بيان زنهاى ֶاسخ دفاعى سيبزمينى، قطعاتى در حدود كمتر از • 11 جفت باز بر روى زل آكارز 1\% (w/v) براى زنهاى PR-3 و PR-5 و PR-10 را نشان داد (شكل ().

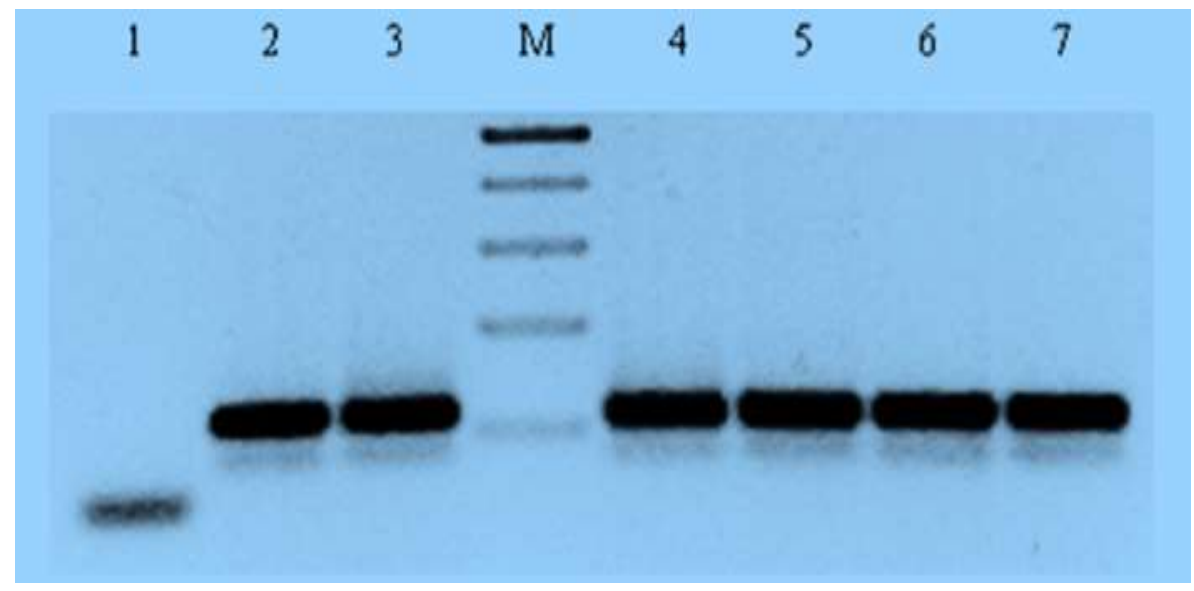

شكل ا. آناليز PCR نمونههاى CDNA جداشده و سنتزشده از بافت غدهاى سيبزمينى. لاين I-

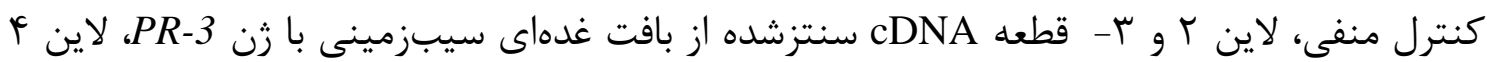

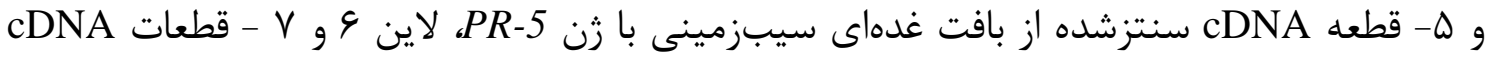

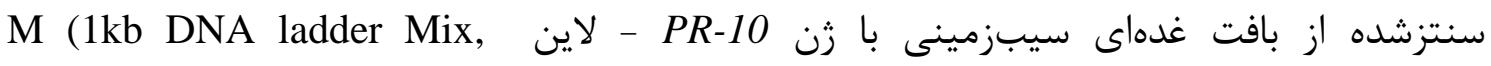

.Fermentas)

Figure 1. PCR analysis of cDNA isolated and synthesized from the tuber disc of potato. - Line 1 - negative control; Line 2,3 - the synthesized cDNA fragment of tuber disc of potato with the $P R-3$; Line 4,5 - the synthesized cDNA fragment of tuber disc of potato with the PR-5; Line 6,7 - the synthesized cDNA fragment of tuber disc of potato with the PR-10; Line M - Molecular DNA weight markers (1 kb DNA ladder Mix, Fermentas). 
مقدار بيان زنهاى PR-3 و PR-5t، PR-10 در سلولهاى بافت غدههاى سيبزمينى رقمهاى اسكارب

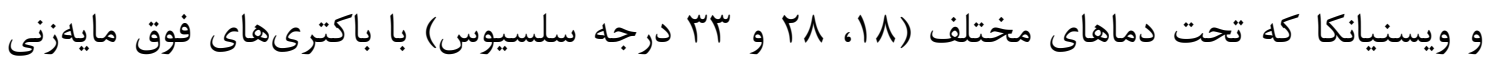
شده بودند، محاسبه و تعيين شد. در جداول r و r مقدار متوسط سطح بيان زنها در سه تكرار با خطاى استاندارد نشان داده شده است. بيشترين مقدار بيان زن براى زن PR-3 در رقم اسكارب تحت آلودكى با باكترى Pc با انكوباسيون در دماى \\ درجه سلسيوس اتفاق افتاد. بيان زن PR-3 در رقم

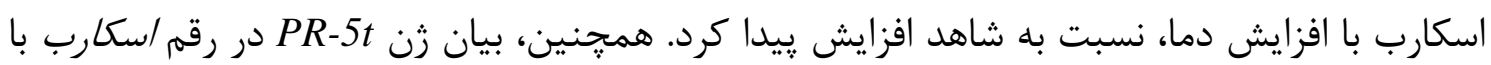
افزايش دما، افزايش پيدا كرد و اين افزايش نسبت به سطح بيان آن در رقم ويسنيانكا بالاتر بود. بالاترين سطح بيان زنها براى زن PR-3 در اثر آلودگى سلولهاى غدهاى رقم ويسنيانكا با سويههاى باكترىهاى Pa 36A و Pa 2A تحت دماهاى ب و و س درجه سلسيوس اتفاق افتاد. زن PR-10 در سطح بالايى در سلولهاى غدهاى رقم ويسنيانكا در دماى \| درجه سلسيوس بيان شد. تحت دماهاى

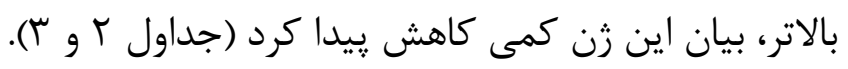

جدول r. سطح بيان زنهاى PR-3، PR-5t و PR-10 در سلولهاى غدهاى سيبزمينى رقم

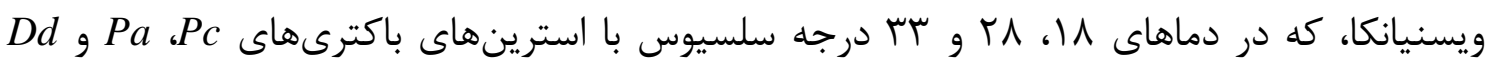

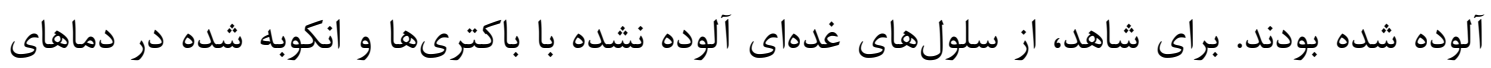

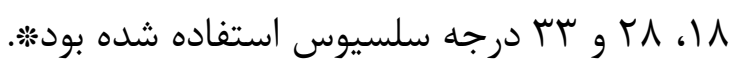

Table 2. Expression levels of genes $P R-10, P R-5 \mathrm{t}, P R-3$ in tuber discs, of potato cultivar, Vesnianka (Relative value of mRNA copies), under temperatures of 18, 28 and $33^{\circ} \mathrm{C}$, infected with strains of $P c, P a$ and $D d$. For control was been used of tuber discs, not infected with bacteria and incubated under temperatures of 18,28 and $33^{\circ}{ }^{\circ} *$.

\begin{tabular}{|c|c|c|c|c|c|c|c|c|c|c|c|c|}
\hline \multirow{2}{*}{ Gene } & \multicolumn{3}{|c|}{ Control } & \multicolumn{3}{|c|}{$\begin{array}{l}\text { Infected with } \\
P c 2 \mathrm{~A}\end{array}$} & \multicolumn{3}{|c|}{$\begin{array}{l}\text { Infected with } \\
\quad \mathrm{Pa} 36 \mathrm{~A}\end{array}$} & \multicolumn{3}{|c|}{$\begin{array}{l}\text { Infected with } \\
D d \text { ENA49 }\end{array}$} \\
\hline & $18^{\circ \mathrm{C}}$ & $28^{\circ} \mathrm{C}$ & $33^{\circ} \mathrm{C}$ & $18^{\circ} \mathrm{C}$ & $28^{\circ} \mathrm{C}$ & $33^{\circ} \mathrm{C}$ & $18^{\circ} \mathrm{C}$ & $28^{\circ} \mathrm{C}$ & $33^{\circ} \mathrm{C}$ & $18^{\circ} \mathrm{C}$ & $28^{\circ} \mathrm{C}$ & $33^{\circ} \mathrm{C}$ \\
\hline PR-3 & 22.7 & 10.5 & 5.5 & $52.0 \mathrm{a}$ & $49.5 \mathrm{ab}$ & $10.6 \mathrm{bc}$ & $104.0 \mathrm{a}$ & $99.0 \mathrm{ac}$ & $78.8 \mathrm{c}$ & $27.9 \mathrm{a}$ & $10.8 \mathrm{ab}$ & $11.3 \mathrm{c}$ \\
\hline PR-5t & 0.01 & 1.1 & 7.2 & $0.5 \mathrm{a}$ & $0.3 \mathrm{ab}$ & $9.8 \mathrm{~b}$ & $1.6 \mathrm{a}$ & $0.4 \mathrm{ac}$ & $2.6 \mathrm{ab}$ & $0.4 \mathrm{a}$ & $0.2 \mathrm{ab}$ & $3.7 \mathrm{c}$ \\
\hline PR-10 & 51.2 & 40.5 & 1.1 & $100.9 \mathrm{a}$ & $2.7 \mathrm{ab}$ & $1.0 \mathrm{ac}$ & $116 \mathrm{~b}$ & $0.5 \mathrm{ab}$ & $4.6 \mathrm{bc}$ & $84.4 \mathrm{a}$ & $0.8 \mathrm{ac}$ & $4.0 \mathrm{ab}$ \\
\hline
\end{tabular}

"الميانگينهاى داراى يك حرف مشترك، اختلاف معنىدارى در سطح ينج درصد در آزمون ندارند.

* Means followed by the same letter in the columns are not significantly different according to LSD test $(\mathrm{p}<0.05)$ 
جدول r. سطح بيان زنهاى PR-3، PR-5t و PR-10 در سلولهاى غدهاى سيبزمينى رقم اسكارب،

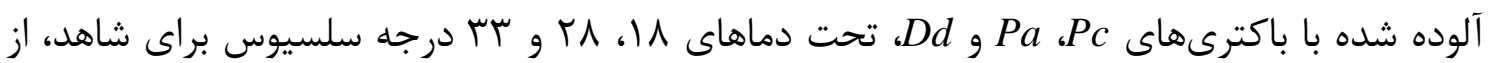

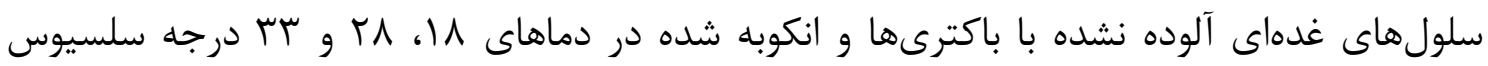
| استفاده شده بودن*.

Table 3. Expression levels of genes $P R-10, P R-5 \mathrm{t}, P R-3$ in tuber discs, of potato cultivar, Scarb(Relative value of mRNA copies), under temperatures of 18, 28 and $33^{\circ}$ ${ }^{\mathrm{C}}$, infected with strains of $P c, P a$ and $D d$. For control was been used of tuber discs, not infected with bacteria and incubated under temperatures of 18,28 and $33^{\circ} \mathrm{C} *$.

Control Infected with $P c$ 2A Infected with $P a 36 \mathrm{~A} \quad$ Infected with $D d$ ENA49

\begin{tabular}{ccccccccccccc} 
Gene & $18{ }^{\circ} \mathrm{C}$ & $28^{\circ} \mathrm{C}$ & $333^{\circ} \mathrm{C}$ & $18{ }^{\circ} \mathrm{C}$ & $28^{\circ} \mathrm{C}$ & $33^{\circ} \mathrm{C}$ & $18^{\circ} \mathrm{C}$ & $28^{\circ} \mathrm{C}$ & $33^{\circ} \mathrm{C}$ & $18^{\circ} \mathrm{C}$ & $28^{\circ} \mathrm{C}$ & $33^{\circ} \mathrm{C}$ \\
\hline PR-3 & 9.7 & 33.05 & 43.5 & $38.9 \mathrm{ab}$ & $5.3 \mathrm{ab}$ & $4.8 \mathrm{ac}$ & $29.9 \mathrm{a}$ & $54.2 \mathrm{ab}$ & $21.9 \mathrm{ac}$ & $3.2 \mathrm{~b}$ & $36.8 \mathrm{ab}$ & $32.4 \mathrm{bc}$ \\
PR-5t & 1.1 & 5.5 & 19.2 & $3.7 \mathrm{a}$ & $1.4 \mathrm{ac}$ & $10.9 \mathrm{~b}$ & $3.7 \mathrm{a}$ & $2.5 \mathrm{ab}$ & $35.5 \mathrm{c}$ & $1.0 \mathrm{a}$ & $29.9 \mathrm{ab}$ & $39.5 \mathrm{c}$ \\
PR-10 & 2.50 & 2.5 & 2,1 & $2.8 \mathrm{~b}$ & $0.03 \mathrm{bc}$ & $0.1 \mathrm{ab}$ & $10.6 \mathrm{a}$ & $0.3 \mathrm{ab}$ & $0.2 \mathrm{ac}$ & $2.0 \mathrm{~b}$ & $0.03 \mathrm{ab}$ & $11.7 \mathrm{ab}$ \\
\hline
\end{tabular}

زدر هر ستون ميانگينهاى داراى حداقل يك حرف مشترك، اختلاف معنىدارى در سطح ينج درصد

* Means followed by the same letter in the columns are not significantly different according to LSD test $(\mathrm{p}<0.05)$.

\section{Discussion}

يزوهشى نشان داده بود كه غدهاى سيبزمينى رقم اسكارب نسبت به بيمارى يوسيدگى نرم باكتريايى در مقايسه با رقم ويسنيانكا زمانى كه به باكترىهاى بيمارىزا آلوده مىشوند، مقاومت بيشترى نشان مى دهند (and Evtushenkov 2010Retyakova )، لذا در اين بروهش از اين رقمها براى مقايسه سطح بيان برخى از زنهاى مرتبط با بيمارىزايى و ارتباط بين بيان اين زنها با القاى مقاومت نسبت به بيمارى يوسيدكى نرم باكتريايى كه مىتواند به وسيله اين باكترها در دماى بهينه براى رشد آنها ايجاد شود، استفاده شد. دماى بجينه براى رشد اين باكترىها ب م درجه سلسيوس تعيين شده بود اما اين تحقيق نشان داد كه در دماهاى سب و \/ درجه سلسيوس نيز سلولهاى اين باكترىها قادر به رشد هستند، لذا در مقدار بالا و رايينتر از دماى بهينه نيز مقدار بيان زنهاى فوق اندازهيرى و تعيين شد (جدولهاى ץ و ب). نشان داده شد كه اختلاف درجه مقاومت سيبزمينى به بيمارى يوسيدگى نرم باكتريايى مىتواند به سطح بيان زنهاى PR ارتباط داشته باشد، همانطور كه اين حالت در اثر آلودگى سيبزمينىهاى مذكور با قارج Masuda et al. ) Phytophthora infestans 2001) و نيز روى رقم Vetraz سيبزمينى (Pasalari and Evtushenkov 2016) نيز رخ داده است. 
آلودگى بافتهاى غدهاى سيبزمينى با بيان همه زنهاى مطالعه شده اتفاق افتاد و نشان داد كه اين سطح بيان زنها به دما، رقم سيبزمينى و سويه باكترىها بستگى دارد. بيشترين سطح بيان زن براى

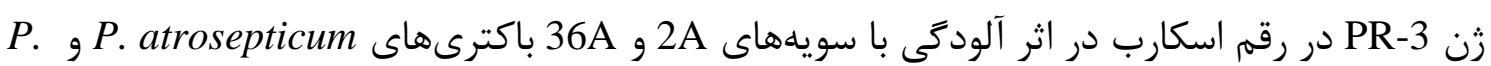
carotovorum ويسنيانكا در دماى \| درجه سلسيوس القا شد. در دماهاى بالاتر از \| درجه سلسيوس، بيان اين زن خيلى كاهش ريدا كرد. براى رقم /سكارب سطح القاى زن PR-5t به اندازه r-•r بار نسبت به رقم

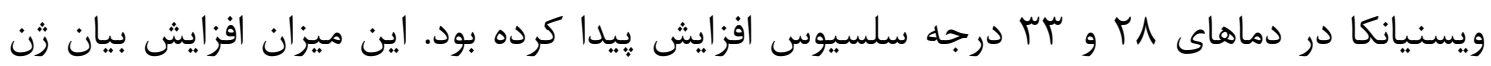
با زمانى كه سيبزمينىهاى مذكور به باكترىها آلوده نشده بودند مقايسه شد كه براى رقم اسكارب بالاتر از رقم ويسنيانكا بود، بنابراين مىتوان عنوان كرد كه در رقم اسكارب مقاومت سيب زمينى به بيمارى يوسيدكى نرم باكتريايى به افزايش سطح بيان زن PR-5t همبستكى و ارتباط معنى دار دارد.

\section{Conclusion}

آزمايشهاى انجام شده، القاى زنهاى مقاومت PR-3، PR-5t و PR-10 را در سلولهاى بافت غدهاى سيبزمينى در پاسخ به آلودگى با سويههاى باكتريهاى مولد يوسيدگى نرم نشان داد. درجه القاى زنهاى مقاومت بستخى به دما و رقم سيبزمينى دارد. در رقم اسكارب سطح بيان زن PR-5t در اثر آلودگى با باكترىهاى مطالعه شده در مقايسه با رقم ويسنيانكا در همه دماهاى اعمال شده كمى بيشتر بود، بنابراين مىتوان نتيجه كرفت كه در رقم اسكارب كه يك رقم نيمهمقاوم به باكترىهاى فوق مىباشد، بين درجه القاى زن PR-5t و مقاومت سيب زمينى به بيمارى بوسيدگى نرم باكتريايى

$$
\text { وابستخى معنى دارى وجود دارد. }
$$

\section{Refrences}

Gholamnezhad J (2017) Plants defense mechanisms against pathogens. Plant Pathology Science 6:24-32. (In Persian with English Abstract).

Hoque ME (2010) In vitro tuberization in potato (Solanum tuberosum L.). Plant Omics 3:7-11.

Liu J (2010) The superfamily of thaumatin-like proteins: its origin, evolution, and expression towards biological function. Plant Cell Reports, 29:419-436.

Livak KJ, Schmittgen ThD (2001) Analysis of relative gene expression data using Realtime quantitative PCR and the $2^{-\Delta \mathrm{Ct}}$ method. Methods 25:402-408. 
Masuda S, Kamada H, Satoh S (2001) Chitinase in cucumber xylem sap. Bioscience, Biotechnology and Biochemistry 65:1883-1885.

Moslemkhani C, Mozafari J (2016) Management of bacterial wilt disease of potato by health assay of seed tubers. Plant Pathology Science 5:62-75. (In Persian with English Abstract).

Pasalari H (2020) Evaluating the resistance of potato tubers under different temperatures related to potato bacterial soft rot disease control. Plant Protection 43:35-44. (In Persian with English Abstract).

Pasalari H, Evtushenkov AN (2016) PR-genes expression in the leaves of transgenic potato plants after glyphosate treatment. Vestnik Belarusian State University. Series, 2, Chemistry, Biology, Geography 1:3-35. (In Russian).

Pontier D, Tronchet M, Rogowsky P, Lam E, Roby D (1998). Activation of hsr 203, a plant gene expressed during incompatible plant-pathogen interactions, is correlated with programmed cell death. Molecular Plant-Microbe Interactions 11:544-554.

Sadravi M (2012) Application of genetic engineering in developing disease-resistant plants. Plant Pathology Science 1:1-9. (In Persian with English Abstract).

Retyakova OM, Evtushenkov AN (2010) Pectolytic and macerating activity of the strains of Pectobacterium carotovorum, Pectobacterium atrosepticum and Dickeya dadantii on the tissues of potato tubers. Potato-Growing: Proccedings 186-190.

Tratsiakova V (2011) Temperature dependence of PR genes expression and potato tissues maceration by strains Pectobacterium and Dickeya. Youth and Progress of Biology, Abstracts book of the VII International Scientific Conference of Students and PhD Students, Minsk, Belarus, P.141. (In Russian).

Van Loon LC, Rep M, Pieterse CM (2011) Significance of inducible Defense-related proteins infected plants. Annual Review of Phytopathology 44:135-162.

Yasuda M, Ishikawa A, Jikumaru Y (2008) Antagonistic interaction between systemic acquired resistance and the abscisic acid-mediated abiotic stress response in Arabidopsis. The Plant Cell 20:1678-1692. 